Article

\title{
Spinach (Spinacea oleracea L.) Response to Salinity: Nutritional Value, Physiological Parameters, Antioxidant Capacity, and Gene Expression
}

\author{
Jorge F. S. Ferreira ${ }^{1, * \mathbb{C}}$, Devinder Sandhu ${ }^{1}{ }^{1}$, Xuan Liu ${ }^{1}$ and Jonathan J. Halvorson ${ }^{2}$ \\ 1 US Salinity Laboratory (USDA-ARS), Riverside, CA 92507, USA; Devinder.Sandhu@ars.usda.gov (D.S.); \\ Xuan.Liu@ars.usda.gov (X.L.) \\ 2 Northern Great Plains Research Laboratory (USDA-ARS), Mandan, ND 58554, USA; \\ Jonathan.Halvorson@ars.usda.gov \\ * Correspondence: Jorge.Ferreira@ars.usda.gov; Tel.: +1-(951)-369-4830
}

Received: 28 September 2018; Accepted: 13 October 2018; Published: 17 October 2018

\begin{abstract}
Scarcity of good-quality irrigation water is a major impediment to meet food demand for a growing world population. Recycled waters may be available locally more affordably, but their higher salinity is a concern. Salinity effects on spinach mineral composition, antioxidant capacity, photosynthesis, and gene expression have not been established. Spinach cv. Raccoon was greenhouse-grown and irrigated with four levels of water salinity of electrical conductivities $\left(\mathrm{EC}_{\mathrm{iw}}\right)$ of 1.4 (control) or ranging from 3.6 to $9.4 \mathrm{dS} \mathrm{m}^{-1}$, combined with three levels of $\mathrm{K}(3,5$, and 7 meq L ${ }^{-1}$ ). Irrigation waters had 2, 20, 40, and $80 \mathrm{meq} \mathrm{L}^{-1}$ of $\mathrm{NaCl}$. After 23 treatment days, plants significantly accumulated $\mathrm{Na}$ and $\mathrm{Cl}$ in shoots and roots with increasing salinity, regardless of the $\mathrm{K}$ concentration in the irrigation water. Plants exhibited no visual symptoms of salt toxicity and there were no differences in shoot growth. Plants maintained their overall concentrations of mineral nutrients, physiological parameters, and oxalic acid across salinity treatments. Leaves retained all their antioxidant capacity at $20 \mathrm{meq} \mathrm{L}^{-1} \mathrm{NaCl}$, and $74 \%$ to $66 \%$ at 40 and $80 \mathrm{meq} \mathrm{L}^{-1}$ $\mathrm{NaCl}$, respectively. Expression analyses of ten genes, that play important role in salt tolerance, indicated that although some genes were upregulated in plants under salinity, compared to the control, there was no association between $\mathrm{Na}$ or $\mathrm{K}$ tissue concentrations and gene expression. Results clearly show that spinach maintains its growth, mineral composition, and antioxidant capacity up to $\mathrm{EC}_{\mathrm{iw}}=9.4 \mathrm{dS} \mathrm{m}^{-1}$. As this salinity is equivalent to a soil salinity of $4.5 \mathrm{dS} \mathrm{m}^{-1}$, spinach can tolerate over two-fold its previously-considered salinity threshold. Thus, growers can cultivate spinach using recycled, saline, waters without detriment to shoot biomass accumulation, and nutritional value.
\end{abstract}

Keywords: abiotic stress; crop yield; salt stress; oxalic acid content; biochemical responses

\section{Introduction}

Commercial spinach cultivated today probably originated from Spinacia tetranda L., a wild edible green found in Nepal. In 647 AD spinach was taken from Nepal to China where it was referred to as the "Persian green." Spinach was introduced by the Moors of North Africa to Spain in the 11th century. By the Middle Ages, spinach was grown and sold throughout the rest of Europe, and it was known in England as the "Spanish vegetable". It was not until the 1400's that spinach became a staple in Mediterranean cooking (https:/ / underwoodgardens.com/history-spinach/).

According to the National Nutrient Database for Standard Reference Release of 1 April 2018 (https://ndb.nal.usda.gov/ndb/foods/show /11457?n1=\%7BQv\%3D1\%7D\&fgcd=\&man=\&lfacet= $\&$ count $=\&$ max $=\&$ sort $=\& q$ lookup $=\&$ offset $=\&$ format $=$ Full $\&$ new $=\&$ measureby $=\& Q v=1 \& d s=\& q t=$ 
$\& q p=\& q a=\& q n=\& q=\& i n g=)$ fresh spinach is rich (per $100 \mathrm{mg}$ of fresh weight, $\mathrm{FW}$ ) in the minerals $\mathrm{K}$ (558 mg), Ca (99 mg) Mg (79 mg), Na (79 mg), P (49 mg), Fe (2.7 mg); and vitamins C (28 mg), betaine (102.6 mg), lutein and zeaxanthin (12.2 mg), B-carotene (5.6 mg), vitamins E (2.0 mg), A (9377 IU), and $\mathrm{K}$, a.k.a. phylloquinone $(483 \mu \mathrm{g})$, folate $(194 \mu \mathrm{g})$, and $2.86 \%$ protein based on FW. However, due to the high concentration of oxalates and phytates in spinach leaves, only $2-5 \%$ of its Ca or P is bioavailable to humans $[1,2]$.

Although spinach can grow in different climates and in soils of low salinity, increasing soil and/or irrigation water salinities can decrease spinach (Spinacia oleracea L.) yield [3]. As an example, 45\% of farmlands $(315,655$ ha) in the West San Joaquim Valley in southern California are affected with high soil salinity (ECe $>4.0 \mathrm{dS} \mathrm{m}{ }^{-1}$ ) [4]. Although excess $\mathrm{Na}^{+}$and $\mathrm{Cl}^{-}$are known to be toxic to glycophytic (salt-sensitive) plants, some species may tolerate $\mathrm{Na}^{+}$and $\mathrm{Cl}^{-}$once adapted to a moderate saline stress. Exposure to high concentrations of $\mathrm{NaCl}$ may adversely affect crop performance due to salinity-induced nutritional imbalance, such as $\mathrm{Na}^{+}$antagonism to $\mathrm{K}^{+}$and $\mathrm{Cl}^{-}$antagonism to $\mathrm{NO}_{3}{ }^{-}$[5]. Although some glycophytic plants of the family Chenopodiaceae [such as sugar beet (Beta vulgaris L.), and spinach] are hypothesized to utilize both $\mathrm{Na}^{+}$and $\mathrm{K}^{+}$for growth and development [6], this has not been explicitly proven for spinach. Other members of the Chenopodiaceae can derive benefit from $\mathrm{Na}^{+}$even when $\mathrm{K}^{+}$is present in sufficient concentrations in the growth medium $[7,8]$. These do not require $\mathrm{K}^{+}$depletion to benefit from $\mathrm{Na}^{+}$, indicating that $\mathrm{Na}^{+}$effects are not solely substitutive [6]. These authors also suggest that the possibility that $\mathrm{Na}^{+}$can act as a generic, benign, osmoticum in plant vacuoles is perfectly plausible due to its similarities with $\mathrm{K}^{+}$. If this proves true, $\mathrm{Na}^{+}$would benefit spinach growth under conditions of saline stress or $\mathrm{K}^{+}$deficiency.

Potassium is one of the three most important mineral nutrients that plays a key role as a cofactor of several enzymes involved in physiological functions in the plant. Although $\mathrm{N}$ can be as (or more) important than $\mathrm{K}^{+}$for growth, the latter can accumulate in leaves in levels two-fold higher than $\mathrm{N}$. In experiments involving salinity, $\mathrm{NaCl}$ accumulation in plant tissues is reported to lead to a significant decrease in $\mathrm{K}^{+}$and $\mathrm{NO}_{3}{ }^{-}$, depending on the species and on the level of salinity used to grow the plants [5,9]. When spinach was grown with 50 and $250 \mathrm{mM}$ of $\mathrm{NaCl}$, approximately $\mathrm{EC}_{\mathrm{iw}}$ of 5 and $25 \mathrm{dS} \mathrm{m}^{-1}$, respectively, plants of the 'Henderson's Hybrid 102' increased their shoot dry weight under both $\mathrm{NaCl}$ concentrations when $\mathrm{KCl}$ was applied at $0.01,0.1,1.0$, and $10 \mathrm{mM}$ [10]. However, the positive response to $\mathrm{K}^{+}$may have been partially because these (mostly low) doses of $\mathrm{KCl}$ were applied instead of the $6.0 \mathrm{mM}$ of $\mathrm{KNO}_{3}$ the plants received in their first two weeks. Thus, although some $\mathrm{K}^{+}$remained in tissues after plants were switched to their salinity treatments, the low nominal concentrations of $\mathrm{KCl}$ may have accounted for their plants low dry weight regardless of the $\mathrm{NaCl}$ doses of either 50 and $250 \mathrm{mM}$. Thus, testing spinach salinity tolerance at higher salinity with sufficient doses of $\mathrm{K}^{+}$may help verify if increasing $\mathrm{K}^{+}$levels may indeed ameliorate salinity effects on spinach.

Although total phenolics and non-enzymatic antioxidants have been studied in response to several stresses, data available is often contrasting in its trend [11], and the roles of plant non-enzymatic antioxidants in response to salinity are not always clear [12]. Although recent experiments on Arabidopsis have shown that overaccumulation of flavonoids have led to a better drought tolerance [13], increased antioxidant capacity of alfalfa was not related to the salinity tolerance of 12 genotypes [14]. When it comes to salinity, we have found no published work on the effect of antioxidant flavonoids on the salinity tolerance of spinach. In addition, there is no published information on the effect of salinity on leaf nutritional characteristics, including antioxidant capacity. Most work on spinach has focused on cultural practices (e.g., irrigation), fertilization, cultivars, and their effect of growth, biomass accumulation [15], and the nutritional value of the crop irrigated with low-salinity water. However, there are no studies that have evaluated the effect of moderate to high-salinity irrigation waters, or the combined effects of high tissue $\mathrm{Na}^{+}$and $\mathrm{Cl}^{-}$, on the nutritional value, antioxidant capacity, and gene expression of spinach. This work aimed to evaluate the combined effect of increasing $\mathrm{Na}^{+}$and $\mathrm{Cl}^{-}$from irrigation, with three levels of $\mathrm{K}^{+}$, on the tissue $\mathrm{NaCl}$ accumulation, fresh shoot biomass, shoot minerals, physiological parameters, soluble oxalates, 
and genetic responses of spinach plants. Based on growth data previously published by colleagues from the US Salinity Laboratory [3,16], our goals were (1) to show that moderate to high tissue $\mathrm{Na}^{+}$ and $\mathrm{Cl}^{-}$accumulation would not alter spinach growth and nutritional value and (2) to show that $\mathrm{Na}^{+}$absorption by spinach would decrease when $\mathrm{K}^{+}$was provided at levels above crop requirement (3 meq $\left.\mathrm{L}^{-1}\right)$.

\section{Materials and Methods}

The experiment, conducted in a greenhouse with spinach (Spinacea oleracea L., cv. Raccoon) between January (seeding) and March (harvest) 2017 in Riverside, CA (Lat. $33.9^{\circ} 58^{\prime} 24^{\prime \prime}$ N, Long. $117^{\circ} 19^{\prime} 12^{\prime \prime} \mathrm{E}$, Alt. $311 \mathrm{~m}$ ) was arranged in a randomized design with ten salinity treatments, including control irrigation water with an electrical conductivity $\left(\mathrm{EC}_{\mathrm{iw}}\right)$ of $1.43 \mathrm{dS} \mathrm{m}^{-1}$. Three seeds were sown directly into six-inch diameter pots filled with three parts non-washed, non-sterile sand and one-part peat moss. After germination, plants were thinned to one plant per pot. Seeding was done on 6 January 2017, and plants grew to eight true leaves (24 February) before being submitted to salinity treatments. Greenhouse temperature was maintained at $25^{\circ} \mathrm{C}$ (days) $/ 17^{\circ} \mathrm{C}$ (nights) under natural illumination. Spinach can grow in California in temperatures ranging from 5 to $30^{\circ} \mathrm{C}$, with optimal growth between $15-18^{\circ} \mathrm{C}$, and can withstand low temperatures of -9 to $-6^{\circ} \mathrm{C}$ [17].

\subsection{Plant Irrigation and Treatments}

For the first 1.5 months (up to eight true leaves), irrigations consisted of only Riverside city water (average $\mathrm{EC}=0.6 \mathrm{dS} \mathrm{m}^{-1}$ and $\mathrm{pH}=7.5$ ) with mineral composition presented in Table 1 . Then, all pots were irrigated daily with modified half-strength Hoagland's solution $\left(\mathrm{EC}_{\mathrm{iw}}=1.43 \mathrm{dS} \mathrm{m}^{-1}, \mathrm{pH}=6.8\right)$ for five days. This Hoagland's solution contained (in $\mathrm{mM}$ ): $\mathrm{Ca}\left(\mathrm{NO}_{3}\right)_{2}$ (3.5), $\mathrm{KNO}_{3}(3.0), \mathrm{KH}_{2} \mathrm{PO}_{4}(0.15)$, $\mathrm{MgSO}_{4}$ (2.0), $\mathrm{Fe}(0.05)$ as sodium ferric diethylenetriamine pentaacetate (NaFe-EDTA), $\mathrm{H}_{3} \mathrm{BO}_{3}(0.023)$, $\mathrm{MnSO}_{4}$ (0.005), $\mathrm{ZnSO}_{4}(0.0004), \mathrm{CuSO}_{4}(0.0002)$, and $\mathrm{H}_{3} \mathrm{MoO}_{4}$ (0.0001). This nutrient solution, without $\mathrm{NaCl}$ or other salts, served as the low-salinity control $\left(\mathrm{EC}_{\mathrm{iw}}=1.43 \mathrm{dS} \mathrm{m}^{-1}\right)$ and the base nutrient solution to all treatments. In addition to the control, pots $(n=5)$ were randomly selected to receive one of 9 other treatment solutions prepared in advance and balanced for salts as presented in Table 1. For each treatment salt concentration, we used a model developed by Suarez and Simunek [18] to predict the ion composition needed to achieve the target $\mathrm{EC}_{\mathrm{iw}}$ values, considering the complementary nature of $\mathrm{Na}^{+}$and $\mathrm{K}^{+}$.

Table 1. Electrical conductivity $\left(\mathrm{EC}_{\mathrm{iw}}\right.$ ) of irrigation waters and chemical composition (in meq $\mathrm{L}^{-1}$ ) of the Riverside city water used to make the salinized water treatments $\mathrm{T} 0$ (control) and T1-T9 used to irrigate spinach. Average water $\mathrm{pH}$ was 6.8. All treatments (T0 to T9) contained $\frac{1}{2}$-strength modified Hoagland's solution as basic fertilization. The concentrations of $\mathrm{HCO}_{3}{ }^{-}, \mathrm{Na}^{+}$, and $\mathrm{Cl}^{-}$came from the Riverside city water. Treatments are described as low in $\mathrm{NaCl}$ (T0, control) or as $\mathrm{T} 1-\mathrm{T} 9$, according to the ratios of $\mathrm{NaCl}: \mathrm{K}$ (in meq $\mathrm{L}^{-1}$ ) concentrations.

\begin{tabular}{|c|c|c|c|c|c|c|c|c|c|c|}
\hline \multirow{3}{*}{$\begin{array}{l}\text { Treatment } \\
\text { City water }\end{array}$} & \multirow{2}{*}{\multicolumn{3}{|c|}{$\frac{\left[\mathrm{Na}^{+}\right]\left[\mathrm{Cl}^{-}\right]\left[\mathrm{K}^{+}\right]}{\left(\mathrm{meq} \mathrm{L}^{-1}\right)}$}} & \multirow{3}{*}{$\begin{array}{c}\mathrm{EC}_{\mathrm{iw}} \\
\left(\mathrm{dS} \mathrm{m}^{-\mathbf{1}}\right) \\
0.6\end{array}$} & \multirow{2}{*}{\multicolumn{2}{|c|}{$\mathrm{NO}_{3}-\mathrm{PO}_{4}{ }^{-3}$}} & \multirow{2}{*}{\multicolumn{2}{|c|}{$\frac{\mathrm{HCO}_{3}{ }^{-} \mathrm{Ca}^{+2}}{\left(\mathrm{meq} \mathrm{L}^{-1}\right)}$}} & \multirow{2}{*}{\multicolumn{2}{|c|}{$\mathrm{Mg}^{+2} \mathrm{SO}_{4}{ }^{-2}$}} \\
\hline & & & & & & & & & & \\
\hline & 2 & 1 & 2 & & 0.38 & 0.001 & 3.3 & 3.2 & 0.78 & 1.4 \\
\hline $\mathrm{T} 0^{+}$(control) & 2 & 1 & 3 & 1.4 & 7.50 & 1.500 & 3.3 & 7.0 & 2.00 & 2.0 \\
\hline $\mathrm{T} 1$ & 20 & 19 & 3 & 3.4 & 7.50 & 1.500 & 3.3 & 7.0 & 2.00 & 2.0 \\
\hline $\mathrm{T} 2$ & 20 & 21 & 5 & 3.7 & 7.50 & 1.500 & 3.3 & 7.0 & 2.00 & 2.0 \\
\hline T3 & 20 & 23 & 7 & 3.8 & 7.50 & 1.500 & 3.3 & 7.0 & 2.00 & 2.0 \\
\hline $\mathrm{T} 4$ & 40 & 39 & 3 & 5.6 & 7.50 & 1.500 & 3.3 & 7.0 & 2.00 & 2.0 \\
\hline T5 & 40 & 41 & 5 & 6.0 & 7.50 & 1.500 & 3.3 & 7.0 & 2.00 & 2.0 \\
\hline T6 & 40 & 43 & 7 & 6.0 & 7.50 & 1.500 & 3.3 & 7.0 & 2.00 & 2.0 \\
\hline T7 & 80 & 79 & 3 & 9.3 & 7.50 & 1.500 & 3.3 & 7.0 & 2.00 & 2.0 \\
\hline $\mathrm{T} 8$ & 80 & 81 & 5 & 9.3 & 7.50 & 1.500 & 3.3 & 7.0 & 2.00 & 2.0 \\
\hline T9 & 80 & 83 & 7 & 9.8 & 7.50 & 1.500 & 3.3 & 7.0 & 2.00 & 2.0 \\
\hline
\end{tabular}

+ T0 was composed of Riverside city water $\left(\mathrm{EC}_{\mathrm{iw}}=0.57\right)$ enriched with $1 / 2$-strength Hoagland's salts, except for $\mathrm{HCO}_{3}{ }^{-}, \mathrm{Na}^{+}$, or $\mathrm{Cl}^{-}$. 
Irrigation with treatment solutions was initiated beginning on 29 February, after the third pair of true leaves was fully expanded and while the fourth pair was developing on all the seedlings. Salinity treatments were applied to plants at once, at their intended salinity level and thereafter irrigated every other day with $100 \mathrm{~mL} \mathrm{pot}^{-1}$ for the first three days to maintain soil saturation; then, with $200 \mathrm{~mL} /$ pot to allow an approximate $10 \%$ leaching fraction. Irrigation with the different treatment solutions continued for 23 days before harvest in plants for analysis.

\subsection{Plant and Soil Mineral Analysis}

Plants were harvested, washed with tap water, then deionized water to remove any mineral impurities remaining from irrigation, blotted dry and separated into roots and shoots. Shoots and roots were oven dried at $65{ }^{\circ} \mathrm{C}$ for $48 \mathrm{~h}$. Tissue mineral concentration was based on shoot dry weight (DW). Chloride was determined from nitric-acetic acid extracts by amperometric titration. The levels of $\mathrm{Na}^{+}$, of the macronutrients $\mathrm{P}, \mathrm{K}, \mathrm{Ca}, \mathrm{Mg}$, and total-S, and of the micronutrients $\mathrm{Fe}, \mathrm{Cu}$, $\mathrm{Mn}, \mathrm{Zn}$, and Mo were determined from nitric acid digestions of the dried, ground, plant material by Inductively Coupled Plasma Optical Emission Spectrometry (ICP-OES, 3300DV, Perkin-Elmer Corp., Waltham, MA, USA). Nitrogen was analyzed by combustion using an Elementar Rapid N Exceed ${ }^{\circledR}$ (https://www.elementaramericas.com/products/nproteinanalyse/rapid-n-exceed.html). After plant harvest, three samples of pot soil were taken at three cardinal points around the pot, down to $10 \mathrm{~cm}$ from soil surface from each pot and combined as one soil sample. Each soil sample weighed about $340 \mathrm{~g}$ and its saturation paste and extracts were analyzed by Inductively Coupled Plasma Optical Emission Spectrometry (ICP-OES) as described for leaves. Soil extract EC and pH were also measured.

\subsection{Oxygen Radical Absorbance Capacity (ORAC), Total Phenolics and Oxalate analyses}

Shoot and root material, assayed for antioxidants and total phenolics, was washed with tap water, then deionized water, blotted dry, and immediately dipped into liquid nitrogen for about $1.5 \mathrm{~min}$. Frozen samples were kept at $-80{ }^{\circ} \mathrm{C}$ until freeze-dried at $-52{ }^{\circ} \mathrm{C}$ to $-55^{\circ} \mathrm{C}$ in a Freeze Dry System (FreeZone 6, Labconco, Kansas City, MO, USA) for $72 \mathrm{~h}$. From each treatment, three out of five plants of each experimental plot (in three replicates) were harvested, lyophilized, and ground in a Wiley mill to pass a $40-$ mesh $(0.635 \mathrm{~mm})$ screen. Plants of each of three replicates were combined into a composite sample for the analyses of oxygen radical absorbance capacity (ORAC), total phenolics (TP), and oxalic acid analyses.

Ground shoot samples $(0.5 \mathrm{~g})$, in triplicates, were mixed with $5 \mathrm{~g}$ of sand and funneled into stainless-steel liquid extraction (PLE) cells (ASE 350, Dionex Corp., Bannockburn, IL, USA) for pressurized extraction. The ASE 350 was set for static: $5 \mathrm{~min}$; flush: 100\%; purge: $60 \mathrm{~s}$ cycle: 2; temperature: $80^{\circ} \mathrm{C}$; and $1500 \mathrm{psi}(10,342 \mathrm{KPa})$. Samples were first extracted with hexane to obtain the lipophilic fraction; then extracted with aqueous acetone (acetone: water:acetic acid $=70: 29.5: 0.5)$ for the hydrophilic fraction. The hexane extract was blown dry using nitrogen gas in a nitrogen evaporator (N-EVAP, Organomation, ASS., Berlin, MA, USA) at $37^{\circ} \mathrm{C}$. The dry sediments were dissolved in $10 \mathrm{~mL}$ of pure acetone, and a $40 \mu \mathrm{L}$ aliquot was diluted for lipophilic oxygen radical absorbance capacity $\left(\mathrm{ORAC}_{\mathrm{Lipo}}\right)$ analysis. The aqueous acetone extract of each sample was brought up to $25 \mathrm{~mL}$ using the acetone-water-acetic acid solution, of which, a $50 \mu \mathrm{L}$ and a $40 \mu \mathrm{L}$ aliquots, were diluted for hydrophilic ORAC analysis $\left(\mathrm{ORAC}_{\mathrm{Hydro}}\right)$. The ORAC assay is based upon the inhibition of the peroxyl-radical-induced oxidation initiated by thermal decomposition of azo-compounds such as [2,2'-azobis(2-amidino-propane) dihydrochloride (AAPH)] [19].

Total phenolics were assayed according to the Folin-Ciocalteu method [20,21] using gallic acid (398225, Sigma-Aldrich, St. Louis, MO, USA) as a standard. A 20- $\mu \mathrm{L}$ aliquot of the ORAC hydrophilic fraction extraction was used for total phenolic analysis. A $20 \mu \mathrm{L}$ sample or gallic acid standard solution at each concentration was pipetted into a cell of a 96-cell microplate, followed by the addition of $100 \mu \mathrm{L}$ of 0.4 N Folin Ciocalteu phenol reagent (stock solution, F9252, Sigma-Aldrich, St. Louis, MO, USA) and the addition of $80 \mu \mathrm{L}$ of $0.943 \mathrm{M} \mathrm{Na}_{2} \mathrm{CO}_{3}$. The plate was covered with a sticky plastic plate cover 
and the color was developed in an incubator at $50^{\circ} \mathrm{C}$ for $5 \mathrm{~min}$. The absorbance was read at $765 \mathrm{~nm}$ using a microplate spectrophotometer (xMark, BIO-RAD, Hercules, CA, USA). Samples were analyzed in triplicate and their total phenol concentration was quantified against a gallic acid standard curve.

Oxalic acid was assayed according to the procedures described in the Technical Bulletin for MAK179, Sigma-Aldrich (https:/ / www.sigmaaldrich.com/content/dam/sigma-aldrich/docs/ Sigma/Bulletin/1/mak179bul.pdf). A ground sample of plant biomass (0.015 g) was transferred to a $1.5 \mathrm{~mL}$ microcentrifuge tube, and $1.0 \mathrm{~mL}$ oxalate assay buffer (MAK179, Sigma-Aldrich, St. Louis, MO, USA) was added to it. The tubes were vortexed for $15 \mathrm{~s}$ and set on ice for $10 \mathrm{~min}$ to extract soluble oxalate ( $\mathrm{Na}$ and $\mathrm{K}$ oxalate) from the samples. The tubes were then centrifuged at 10,000 $\mathrm{g}$ for $10 \mathrm{~min}$. The supernatant was diluted 5 -fold, $2 \mu \mathrm{L}$ of the diluted supernatant was used for oxalic acid enzymatic-colorimetric assay in a 96-cell microplate, according to the procedures described in the Technical Bulletin for MAK179 (link above). The plate cells were read at $450 \mathrm{~nm}$ using a microplate spectrophotometer (xMark, BIO-RAD, Hercules, CA, USA). Samples were analyzed in duplicates.

\subsection{Leaf Photosynthetic Performance}

A Li-Cor 6400 Photosynthesis System (Li-Cor, Lincoln, NE, USA) was used for the measurement of leaf gas exchange of leaf net photosynthesis ( $\mathrm{Pn})$, stomatal conductance (gs), and transpiration rate (Tr). All the measurements were taken on the youngest fully expanded leaves exposed to sunlight. Measurements were taken at a photosynthetic photon flux density, $1200 \mu \mathrm{mol}_{\text {photon }} \mathrm{m}^{-2} \mathrm{~s}^{-1}$ provided by a red LED light diode source emitting at $670 \mathrm{~nm}$ mounted on the top of leaf chamber; with an operational or chamber ambient $\mathrm{CO}_{2}$ concentration of $400 \mu \mathrm{mol} \mathrm{CO} \mathrm{mol}^{-1}$; and with a leaf to air vapor pressure deficit of $0.90-2.9 \mathrm{kPa}$. Chamber air temperature during measurements fluctuated from $24-29^{\circ} \mathrm{C}$, close to the outside air temperature, due to poor control by the chamber cooling fan. Leaf water use efficiency (WUE) was calculated using formula WUE $=\mathrm{Pn} / \mathrm{Tr}$, expressed as $\mu \mathrm{mol} \mathrm{CO} 2$ $\left.\mathrm{mmol}^{-1} \mathrm{H}_{2} \mathrm{O}\right)$. Licor data was taken for one leaf of each potted plant $(n=5)$.

\subsection{Gene Expression}

Ten genes known to play important role in salt tolerance were selected based on their functional characterization in Arabidopsis. The Arabidopsis gene sequences were used in Basic Local Alignment Search Tool (BLAST) analyses against the spinach genome to identify corresponding genes in spinach [22]. For each gene, the spinach gene sequence with the highest level of homology to the Arabidopsis gene was selected for analysis. quantitative Reverse Transcription-PCR (qRT-PCR) primers were designed for each gene using the NCBI Primer-BLAST program (Table S1). To avoid PCR amplification from genomic DNA, at least one of the PCR primers out of each pair was designed from two exons flanking an intron.

Leaf and root samples were collected for RNA isolation 8 days after initiating the salt treatment. Samples were frozen immediately in liquid nitrogen and RNA was isolated using TRIzol ${ }^{\circledR}$ reagent (Invitrogen, Carlsbad, CA, USA). Contaminating DNA was removed by treating RNA samples with DNase I, following manufacturer's instructions (Thermo Scientific, Waltham, MA, USA). iTaq ${ }^{\text {TM }}$ Universal SYBR ${ }^{\circledR}$ Green One-Step Kit was used to perform qRT-PCR reactions in BioRad CFX96 System (Bio-Rad Laboratories, Hercules, CA, USA). qRT-PCR reactions were carried out in $10 \mu \mathrm{L}$ volume containing $100 \mathrm{ng}$ total RNA, $0.75 \mu \mathrm{M}$ of each of the primers, $0.125 \mu \mathrm{L}$ iScript ${ }^{\mathrm{TM}}$ Reverse Transcriptase and $5 \mu \mathrm{L}$ of $2 x$ one-step SYBR ${ }^{\circledR}$ Green Reaction mix. The alfalfa Actin (Act) and Actin depolymerization factor (Actdf) genes were used as reference genes in the expression analyses. The PCR conditions were as follows: $50^{\circ} \mathrm{C}$ for $10 \mathrm{~min}, 95^{\circ} \mathrm{C}$ for $1 \mathrm{~min}$, then 40 cycles of $95^{\circ} \mathrm{C}$ denaturation for $10 \mathrm{~s}, 57^{\circ} \mathrm{C}$ annealing for $30 \mathrm{~s}$, and $68^{\circ} \mathrm{C}$ extension for $30 \mathrm{~s}$. The relative quantity of the target gene was normalized by comparing cycle threshold values with the reference genes $(\Delta \Delta \mathrm{Cq})$ to calculate expression differences [23]. The normalized expression was calculated using the following equation:

Normalized Expression $_{\text {sample }(\mathrm{GOI})}=\left[\mathrm{RQ}_{\text {sample }(\mathrm{GOI})}\right] /\left[\mathrm{RQ}_{\text {sample }(\operatorname{Ref~1)}} \times \mathrm{RQ}_{\text {sample (Ref 2) }} \times \ldots \mathrm{RQ}_{\text {sample }(\operatorname{Ref} \mathrm{n})}\right]^{1 / \mathrm{n}}$. 
where GOI is gene of interest, RQ represents relative sample quantity, Ref is the reference target (gene or sequence) in a run (includes one or more reference targets in each samples), and $n=$ number of reference targets. Amplification specificity was tested using melt curve analysis by increasing the temperature $95^{\circ} \mathrm{C}$ for $10 \mathrm{~s}$ and back to $65^{\circ} \mathrm{C}$ for $5 \mathrm{~s}$ followed by incremental increases of $0.5^{\circ} \mathrm{C} / \mathrm{cycle}$ up to $95^{\circ} \mathrm{C}$. A list of the primers used to evaluate gene expression is provided (Table S2).

\subsection{Statistical Analysis}

Main effects and interaction of salinity, $\mathrm{Na}^{+}$, and $\mathrm{K}^{+}$on $\mathrm{Na}^{+}$and $\mathrm{K}^{+}$in both roots and shoots was tested using GLM procedures for split plot design in SAS (version 9.3; SAS Institute, Cary, NC, USA). Significance of specific differences were analyzed among the levels of $\mathrm{K}^{+}$and $\mathrm{Na}^{+}$, and salinity, and among the ten levels (treatments) at each salinity and salt composition for shoots and roots separately at $p \leq 0.05$ using the Bonferroni multi-comparison method in GLM procedure of SAS. Significant differences between leaf and root tissues were evaluated at $p \leq 0.05$ by the $t$-test procedure in SAS.

\section{Results}

\subsection{Salt Increase in Spinach Tissues and Mineral Tissue Composition}

Treatments will be referred to as control (T0) or denominated as treatments $\mathrm{T} 1$ to T9 according to the concentration ratio of $\mathrm{NaCl}: \mathrm{K}^{+}$in meq $\mathrm{L}^{-1}$ used to irrigate potted plants (Figure 1, Table 1). Salinity treatments significantly increased both $\mathrm{Na}$ and $\mathrm{Cl}$ in roots and shoots of spinach. Average tissue $\mathrm{Cl}$ accumulation was generally $4-8$ times higher than $\mathrm{Na}$ in roots, and 1.6-2.5 higher than $\mathrm{Na}$ in shoots. Spinach shoots accumulated 1.3 to 3.0 times more $\mathrm{Na}^{+}$than roots at each increase in salinity, while $\mathrm{Cl}$ levels were similar for roots and shoots at each salinity increase (Table 2).

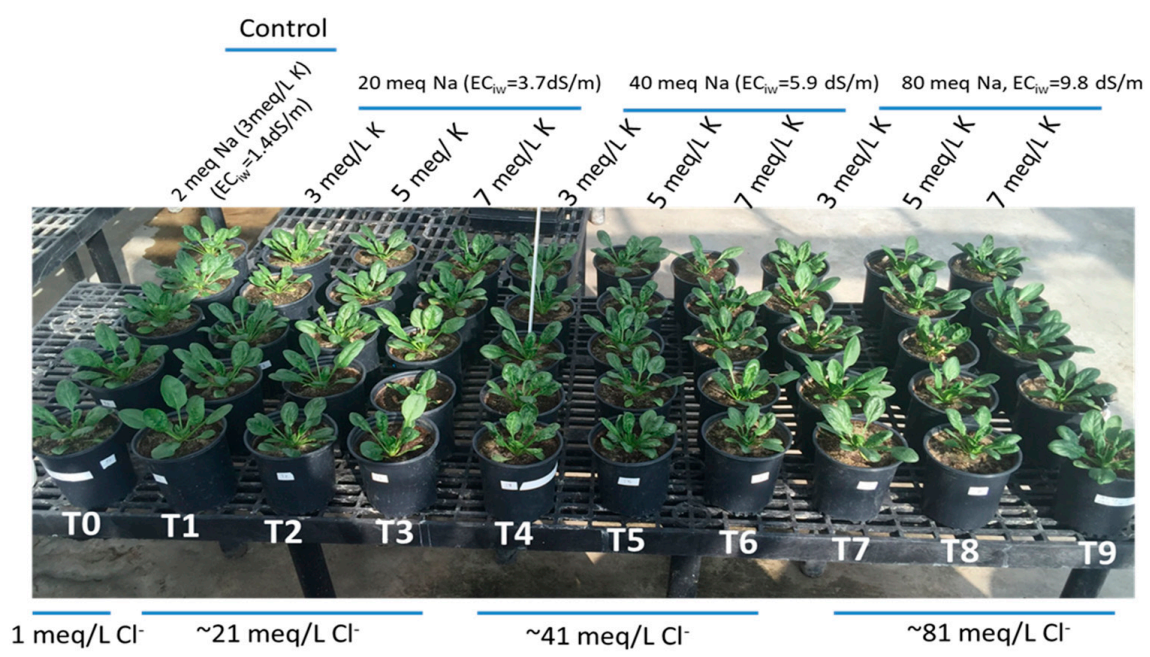

Figure 1. Spinach plants of the cultivar Raccoon 23 days after exposure to irrigation water salinities with electrical conductivities $\left(\mathrm{EC}_{\mathrm{iw}}\right)$ ranging from $1.4 \mathrm{dS} \mathrm{m}^{-1}\left(2 \mathrm{meq} \mathrm{L}{ }^{-1} \mathrm{NaCl}\right)$ to $9.8 \mathrm{dS} \mathrm{m}^{-1}\left(80 \mathrm{meq} \mathrm{L}^{-1}\right.$ $\mathrm{NaCl}$ ). $\mathrm{NO}_{3}{ }^{-}$and $\mathrm{SO}_{4}{ }^{-2}$ were kept constant at 7.5 and 2.0 meq $\mathrm{L}^{-1}$, respectively, and $\mathrm{pH}=7.3$. Treatments were labeled T0 (control, 2 meq L ${ }^{-1} \mathrm{Na}^{+}, 1$ meq $\left.\mathrm{L}^{-1} \mathrm{Cl}^{-}, 3 \mathrm{meq} \mathrm{L}{ }^{-1} \mathrm{~K}^{+}\right)$to $\mathrm{T} 9\left(80 \mathrm{meq} \mathrm{L}^{-1}\right.$ $\mathrm{NaCl}: 7$ meq $\mathrm{L}^{-1} \mathrm{~K}^{+}$).

As $\mathrm{NaCl}$ water concentrations increased from $\mathrm{T} 0$ (control) to $20 \mathrm{meq} \mathrm{L}^{-1}$, the average pot medium (3 parts sand:1 part peat moss) accumulated 5.3-fold more $\mathrm{Na}^{+}$and 18.7-fold more $\mathrm{Cl}^{-}$in the soil saturated paste. When concentrations of $\mathrm{NaCl}$ doubled from 20 to 40 and from 40 to 80 meq $\mathrm{L}^{-1}$, pot medium had their concentrations of both $\mathrm{Na}^{+}$and $\mathrm{Cl}^{-}$also increased by approximately twice at each salinity increase. Both $\mathrm{Na}$ and $\mathrm{Cl}$ increased in roots and shoots with increasing salinity, regardless of $\mathrm{K}$ doses (Table 2). 
Table 2. Sodium (Na), chloride $(\mathrm{Cl})$, macronutrients and dry weight of spinach plants $\mathrm{cv}$. Raccoon irrigated with waters of $20-80 \mathrm{meq} \mathrm{L}^{-1}$ of $\mathrm{NaCl}$ and three potassium $(\mathrm{K})$ concentrations. Data are means ( $n=2-5$ for roots, and $4-5$ for shoots). $\mathrm{K}^{+}$was applied as $\mathrm{KNO}_{3}$ or $\mathrm{KCl}$. Missing data (-) resulted from insufficient material for analysis.

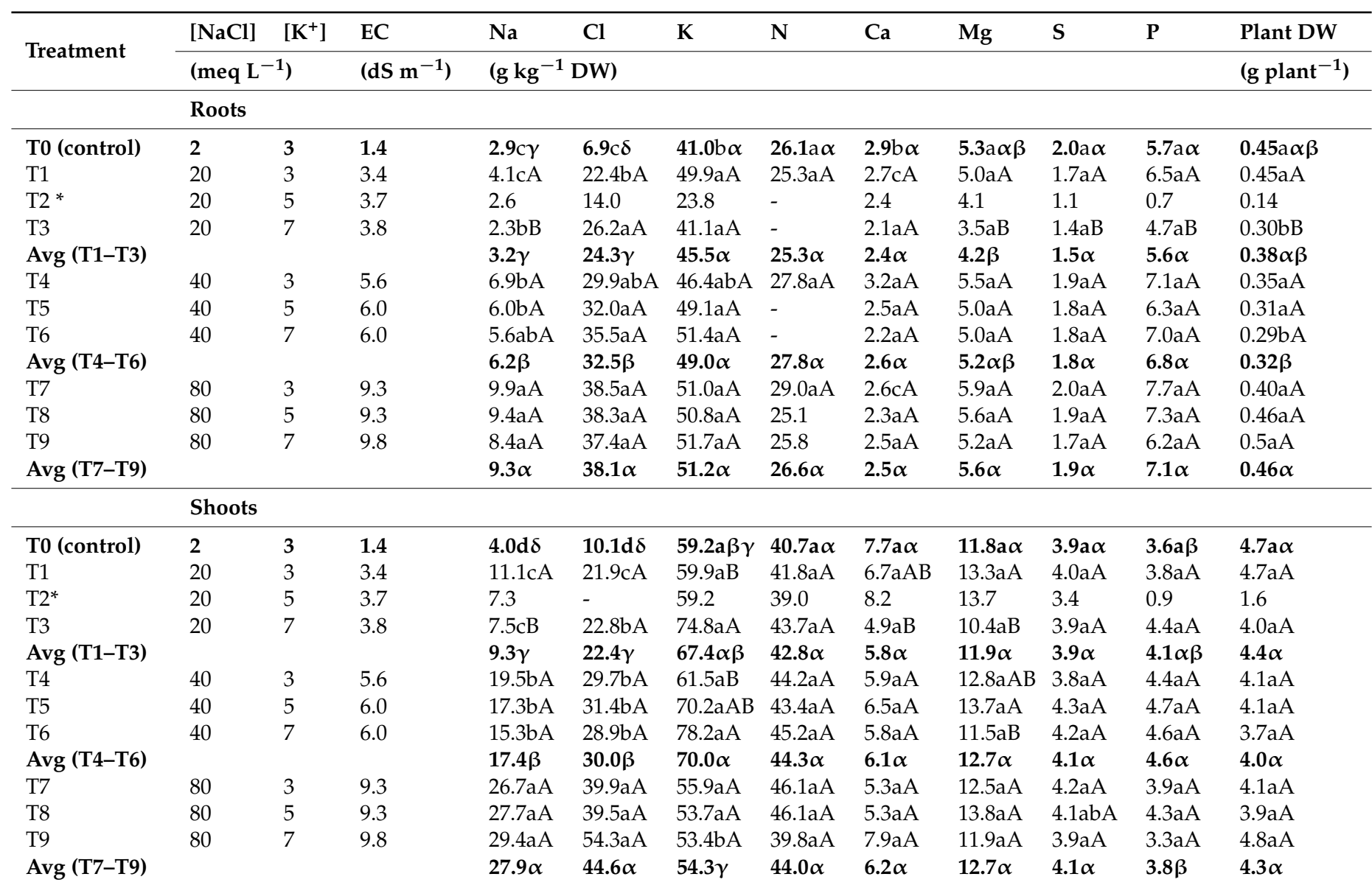

Lowercase letters show significant $(p \leq 0.05)$ difference among different $\mathrm{NaCl}$ treatments within a tissue type and at the same $\mathrm{K}$ level. Capital letters indicate significant $(p \leq 0.05)$ differences among the three $\mathrm{K}$ treatments within a tissue type at the same $\mathrm{NaCl}$ treatment level. Greek letters show significant $(p \leq 0.05)$ average (Avg) differences among different salinity $(\mathrm{NaCl})$ treatments within a tissue type. * Treatment omitted from statistical analysis of biomass and minerals, thus no letters. 
In shoots, there were no significant changes in average macronutrients across $\mathrm{K}$ doses, but average $\mathrm{K}$ (treatments T7-T9) was significantly lower when plants were irrigated with 80 meq $\mathrm{L}^{-1}$ of $\mathrm{NaCl}$ (Table 2). Root average micronutrients remained stable across $\mathrm{K}$ doses, but $\mathrm{Mn}$ and $\mathrm{Zn}$ increased significantly at the two highest salinity treatments. In shoots, only Mn increased significantly at the highest salinity treatments (Table S1). Average concentration of mineral nutrients in shoots were: $6.3 \%(\mathrm{~K}), 4.3 \%(\mathrm{~N}), 1.2 \%(\mathrm{Mg}), 0.64 \%(\mathrm{Ca})$, and $0.4 \%(\mathrm{P})$. Shoot $\mathrm{Na}$ concentrations ranged from 0.4 to $2.8 \%$ and shoot $\mathrm{Cl}$ from 1.0 to $4.5 \%$ (Table 2), while Fe ranged from 177-205 ppm (Table S1). Estimation of the leaf protein concentration using the specific N:Protein conversion factor of 4.39 established for vegetables, including spinach [24] produced a shoot protein content of $18.9 \%$. According to these authors, the conversion factor of 4.39 accounts for non-protein $\mathrm{N}$ in spinach, which is $27 \%$ of the total $\mathrm{N}$ and is more accurate than the general conversion factor of 6.25 .

\subsection{Shoot Biomass, Antioxidant Capacity, and Oxalic Acid}

Average shoot biomass remained constant across salinity and $\mathrm{K}$ levels (Table 2). Shoot average hydrophilic $\left(\mathrm{ORAC}_{\mathrm{Hydro}}\right)$ antioxidant capacity and total phenolics both decreased significantly as salinity increased from T0 (control) to T9, while oxalic acid levels were unaffected by the salinity levels tested (Table 3$)$. The average spinach total antioxidant capacity $\left(O R A C_{\text {Hydro }}+\mathrm{ORAC}_{\text {Lipo }}\right)$ also decreased from 214 (T0) to 150 (T7-T9) as salinity increased. Control spinach shoots had a lipophilic antioxidant capacity of 26 meq TE $\mathrm{g}^{-1} \mathrm{DW}$. Total phenolics ranged from 3 to $4 \mathrm{mg}$ of gallic acid equivalent per gram of dry weight (mg GAE g $\left.{ }^{-1} \mathrm{DW}\right)$. Spinach shoots ranged in their oxalic acid concentrations from 7.6 to $9.7 \%(w / w)$ (Table 3$)$.

Table 3. Shoot antioxidant capacity of hydrophilic fraction measured $\left(\mathrm{ORAC}_{\mathrm{Hydro}}\right)$ and lipophilic fraction $\left(\mathrm{ORAC}_{\text {Lipo }}\right.$ ) (measured as oxygen radical absorbance capacity) with total phenol content $\left(\mathrm{TP}_{\text {Hydro }}\right)$ of hydrophilic fraction, and oxalic acid concentration (Oxal) of spinach plants (Spinacia oleracea L., cv. Raccoon) irrigated with saline waters of three $\mathrm{NaCl}$ concentrations in respect to three $\mathrm{KCl}$ concentrations. Data are means with sample size (pot, one plant per pot) $n=4-5$. TE: trolox equivalent, GAE: gallic acid equivalent. $\mathrm{Na}^{+}$was applied as $\mathrm{NaCl}$ and $\mathrm{K}^{+}$was applied as $\mathrm{KNO}_{3}$ or $\mathrm{KCl}$.

\begin{tabular}{|c|c|c|c|c|c|c|c|}
\hline \multirow{3}{*}{$\begin{array}{l}\text { Treatment } \\
\text { T0 (control) }\end{array}$} & \multirow{2}{*}{\multicolumn{2}{|c|}{$\frac{[\mathrm{NaCl}]\left[\mathrm{K}^{+}\right]}{\left(\mathrm{meq} \mathrm{L}^{-1}\right)}$}} & \multirow{3}{*}{$\begin{array}{l}\mathrm{EC} \\
\left(\mathrm{dS} \mathrm{m}^{-1}\right) \\
1.4\end{array}$} & \multirow{2}{*}{\multicolumn{2}{|c|}{$\begin{array}{c}\text { ORAC }_{\text {Hydro }} \text { ORAC }_{\text {Lipo }} \\
\left(\mu \mathrm{mol} \mathrm{TE} \mathrm{g}^{-1} \mathrm{DW}\right)\end{array}$}} & \multirow{3}{*}{ 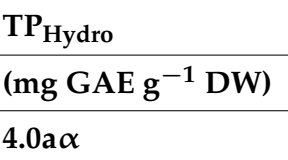 } & \multirow{3}{*}{$\begin{array}{l}\text { Oxalate } \\
\left(\mathrm{mg} \mathrm{g}^{-1} \mathrm{DW}\right) \\
76.1 \mathrm{a} \alpha\end{array}$} \\
\hline & & & & & & & \\
\hline & 2 & 3 & & $188.1 \mathrm{a} \alpha$ & $26.2 \mathrm{a} \alpha \beta$ & & \\
\hline T1 & 20 & 3 & 3.4 & $171.2 \mathrm{aA}$ & $34.6 a \mathrm{~A}$ & 3.6abA & $95.2 \mathrm{aA}$ \\
\hline $\mathrm{T} 2$ & 20 & 5 & 3.7 & $234.0 \mathrm{aA}$ & $13.6 \mathrm{bB}$ & $4.9 \mathrm{aA}$ & $76.5 \mathrm{aA}$ \\
\hline $\mathrm{T} 3$ & 20 & 7 & 3.8 & $144.9 \mathrm{aA}$ & $32.8 \mathrm{aAB}$ & $3.8 \mathrm{aA}$ & $80.7 \mathrm{aA}$ \\
\hline Avg (T1-T3) & & & & $158.0 \alpha \beta$ & $33.7 \alpha \beta$ & $3.7 \alpha \beta$ & $88.0 \alpha$ \\
\hline $\mathrm{T} 4$ & 40 & 3 & 5.6 & $135.9 \mathrm{aA}$ & $36.6 \mathrm{aA}$ & $3.3 \mathrm{bA}$ & $93.4 \mathrm{aA}$ \\
\hline T5 & 40 & 5 & 6.0 & $165.5 \mathrm{aA}$ & $33.3 \mathrm{aA}$ & $3.4 \mathrm{aA}$ & $95.8 \mathrm{aA}$ \\
\hline $\mathrm{T} 6$ & 40 & 7 & 6.0 & $113.3 \mathrm{aA}$ & $34.6 \mathrm{aA}$ & $3.0 \mathrm{aA}$ & $103.0 \mathrm{aA}$ \\
\hline Avg (T4-T6) & & & & $138.2 \alpha \beta$ & $34.8 \alpha$ & $3.2 \beta$ & $97.4 \alpha$ \\
\hline $\mathrm{T} 7$ & 80 & 3 & 9.3 & $129.9 \mathrm{aA}$ & $26.7 \mathrm{aA}$ & $3.3 \mathrm{bA}$ & $92.4 \mathrm{aA}$ \\
\hline T8 & 80 & 5 & 9.3 & $108.6 \mathrm{aA}$ & 23.5abA & $3.0 \mathrm{aA}$ & $98.8 \mathrm{aA}$ \\
\hline $\mathrm{T} 9$ & 80 & 7 & 9.8 & $131.9 \mathrm{aA}$ & $22.6 \mathrm{aA}$ & $3.2 \mathrm{aA}$ & $84.2 \mathrm{aA}$ \\
\hline Avg (T7-T9) & & & & $123.5 \beta$ & $24.3 \beta$ & $3.2 \beta$ & $91.8 \alpha$ \\
\hline
\end{tabular}

Lowercase letters show significant $(p \leq 0.05)$ difference among different $\mathrm{Na}$ treatments within shoots at the same $\mathrm{K}$ level. Capital letters indicate significant $(p \leq 0.05)$ difference among the three $\mathrm{K}$ treatments at the same $\mathrm{NaCl}$ treatment level. Greek letters show significant $(p \leq 0.05)$ average (Avg) difference among different $\mathrm{NaCl}$ treatments, across potassium doses.

\subsection{Leaf Photosynthetic Performance}

Physiological parameters were evaluated 18 days after the plants started receiving treatments. Although there was no difference in SPAD chlorophyll levels, Photosynthetic rate (Pn), stomatal conductance (gs), and transpiration (Tr) decreased (significantly or not) in treatments that had the highest salinity (T7-T9), while water use efficiency (WUE) increased significantly with salinity (Table 4). 
Table 4. Leaf SPAD chlorophyll readings, net photosynthetic rate $\left(\mathrm{Pn}, \mu \mathrm{mol} \mathrm{CO} \mathrm{m}^{-2} \mathrm{~s}^{-1}\right)$, stomatal conductance (gs, mol $\mathrm{H}_{2} \mathrm{O} \mathrm{m}^{-2} \mathrm{~s}^{-1}$ ), transpiration rate $\left(\mathrm{Tr}, \mathrm{mmol} \mathrm{H}_{2} \mathrm{O} \mathrm{m}^{-2} \mathrm{~s}^{-1}\right.$ ), and water use efficiency (WUE, $\mu \mathrm{mol} \mathrm{CO} \mathrm{Cmol}^{-1} \mathrm{H}_{2} \mathrm{O}$ ) of spinach plants (Spinacea oleracea, cv. Raccoon) irrigated with saline waters of three $\mathrm{NaCl}$ concentrations in respect to three $\mathrm{KCl}$ concentrations. Data are means of one leaf per plant, per pot $(n=5)$ or averages $(\mathrm{Avg})$ of three $\mathrm{K}^{+}$doses $(n=15)$ within the same $\mathrm{NaCl}$ dose.

\begin{tabular}{|c|c|c|c|c|c|c|c|c|}
\hline \multirow{3}{*}{ Treatment } & $\mathrm{NaCl}$ & $\mathrm{K}^{+}$ & $\mathrm{EC}_{\mathrm{iw}}$ & SPAD & Pn & gs & $\operatorname{Tr}$ & WUE \\
\hline & (meq L & $-1)$ & $\left(\mathrm{dS} \mathrm{m}^{-1}\right)$ & & $\begin{array}{l}(\mu \mathrm{mol} \mathrm{CO} 2 \\
\mathrm{m}^{-2} \mathrm{~s}^{-1)}\end{array}$ & $\begin{array}{l}\left(\mathrm{mol} \mathrm{H}_{2} \mathrm{O}\right. \\
\mathrm{m}^{-2} \mathrm{~s}^{-1)}\end{array}$ & $\begin{array}{l}\left(\mathrm{mmol} \mathrm{H}_{2} \mathrm{O}\right. \\
\mathrm{m}^{-2} \mathrm{~s}^{-1)}\end{array}$ & $\begin{array}{l}\left(\mu \mathrm{mol} \mathrm{CO} \mathrm{C}_{2}\right. \\
\left.\mathrm{mmol}^{-1} \mathrm{H}_{2} \mathrm{O}\right)\end{array}$ \\
\hline & \multicolumn{8}{|c|}{19 DAYS AFTER TREATMENT } \\
\hline T0 (control) & 2 & 3 & 1.4 & $66.9 \mathrm{a} \alpha$ & $20.1 \mathrm{ab} \alpha$ & $0.37 \mathrm{a} \alpha$ & $5.8 \mathrm{a} \alpha$ & $3.4 \mathrm{c} \beta$ \\
\hline $\mathrm{T} 1$ & 20 & 3 & 3.4 & $67.9 \mathrm{aA}$ & $20.7 \mathrm{aA}$ & $0.32 \mathrm{aA}$ & $4.9 \mathrm{bA}$ & $4.2 \mathrm{abA}$ \\
\hline $\mathrm{T} 2$ & 20 & 5 & 3.7 & $64.6 \mathrm{aA}$ & $12.9 \mathrm{bC}$ & $0.20 \mathrm{bB}$ & $3.1 \mathrm{aC}$ & $4.2 \mathrm{aA}$ \\
\hline $\mathrm{T} 3$ & 20 & 7 & 3.8 & $66.6 \mathrm{aA}$ & $18.0 \mathrm{aAB}$ & $0.32 \mathrm{aA}$ & $4.0 \mathrm{aB}$ & $4.5 \mathrm{aA}$ \\
\hline Avg (T1-T3) & & & & $67.3 \alpha$ & $19.4 \alpha$ & $0.32 \alpha$ & $4.5 \beta$ & $4.4 \alpha$ \\
\hline $\mathrm{T} 4$ & 40 & 3 & 5.6 & $68.5 \mathrm{aA}$ & 19.0abA & $0.34 \mathrm{aA}$ & $4.5 \mathrm{bcA}$ & $4.2 \mathrm{abA}$ \\
\hline T5 & 40 & 5 & 6.0 & $66.9 \mathrm{aA}$ & $17.3 \mathrm{aA}$ & $0.32 \mathrm{aA}$ & $3.9 \mathrm{aAB}$ & $4.4 \mathrm{aA}$ \\
\hline $\mathrm{T} 6$ & 40 & 7 & 6.0 & $67.5 \mathrm{aA}$ & $16.9 \mathrm{aA}$ & $0.36 \mathrm{aA}$ & $3.9 \mathrm{aB}$ & $4.4 \mathrm{aA}$ \\
\hline Avg (T4-T6) & & & & $67.6 \alpha$ & $17.7 \alpha \beta$ & $0.34 \alpha$ & $4.1 \beta \gamma$ & $4.3 \alpha$ \\
\hline $\mathrm{T} 7$ & 80 & 3 & 9.3 & $69.3 \mathrm{aA}$ & $17.6 \mathrm{bA}$ & $0.26 \mathrm{aA}$ & $3.9 \mathrm{cAB}$ & $4.5 \mathrm{aA}$ \\
\hline T8 & 80 & 5 & 9.3 & $67.9 \mathrm{aA}$ & $17.5 \mathrm{aA}$ & $0.20 \mathrm{bAB}$ & $4.1 \mathrm{aA}$ & $4.3 \mathrm{aA}$ \\
\hline T9 & 80 & 7 & 9.8 & $66.7 \mathrm{aA}$ & $16.0 \mathrm{aA}$ & $0.19 \mathrm{bB}$ & $3.3 \mathrm{bB}$ & $4.9 \mathrm{aA}$ \\
\hline Avg (T7-T9) & & & & $68.0 \alpha$ & $17.0 \beta$ & $0.22 \beta$ & $3.8 \gamma$ & $4.6 \alpha$ \\
\hline
\end{tabular}

Lowercase letters show significant $(p<0.05)$ difference among different Na treatments for shoots at the same $\mathrm{K}$ level. Capital letters show significant $(p \leq 0.05)$ difference among the three $\mathrm{K}$ treatments within same collection date at the same $\mathrm{Na}$ treatment level. Greek letters show significant $(p \leq 0.05)$ average (Avg) differences among different sodium $(\mathrm{NaCl})$ treatments, across $\mathrm{K}^{+}$doses.

\subsection{Gene Expression Analyses}

A set of 10 spinach genes (SoSOS1, SoSOS2, SoSOS3, SoNHX1, SoNHX2, SoERF1, SoHKT1, SoAKT1, SoERS1 and SoSAL1), selected based on functional conservation to genes known to play important role in salt tolerance in Arabidopsis, was used to study gene expression in different salt treatments. Average relative expressions of SoSOS1 ( $p=0.003)$, SoSOS2 $(p<0.001)$, SoERF1 $(p=0.008)$ and SoAKT1 $(p=0.006)$ were higher in roots as compared to leaves and expressions of SoNHX2 $(p=0.025)$ and SoSAL1 $(p=0.028)$ were higher in leaves as compared to roots (Figure 2). SoSOS3 expression in roots was significantly higher in treatments containing 40 meq $\mathrm{L}^{-1} \mathrm{Na}^{+}(\mathrm{T} 4, \mathrm{P}=0.01 ; \mathrm{T} 5, p=0.01 ; \mathrm{T} 6, p=0.03)$ as compared to the control. Similarly, SoNHX1 expression in roots was significantly higher than T0 in treatments T4 $(p=0.02), \mathrm{T} 5(p=0.03)$ and T6 $(p=0.01)$. Among all the treatments, one with 40 meq L $\mathrm{L}^{-1}$ $\mathrm{Na}^{+}$and 7 meq L ${ }^{-1} \mathrm{~K}^{+}$displayed highest level of expression for SoSOS1, SoNHX1 and SoERF1 in roots and SoSOS3 and SoNHX1 in leaves (Figure 2). In roots, SoNHX1 was upregulated in all treatments as compared to control, with highest expression at 40 meq $\mathrm{L}^{-1} \mathrm{Na}^{+}$and $7 \mathrm{meq} \mathrm{L}{ }^{-1} \mathrm{~K}^{+}$(Figure 2). At the highest salinity level $\left(\mathrm{EC}=9.2 \mathrm{dS} \mathrm{m}^{-1}\right)$ and the lowest $\mathrm{K}^{+}$level $\left(3 \mathrm{meq} \mathrm{L}^{-1}\right)(\mathrm{T} 7)$, SoERS1 and SoSAL1 showed highest expression in leaves as compared to the other treatments. SoSOS2 expression in root was the highest for the treatment with the maximum concentration of $\mathrm{K}^{+}\left(7 \mathrm{meq}{ }^{-1}\right)$ at each salinity level. Interestingly, the relative expression patterns of SoSOS3 and SoNHX1 were extremely similar. Although there were some differences in expression in treatments as compared to the control, there was no significant correlation between different salinity levels and gene expression (Table 5). 

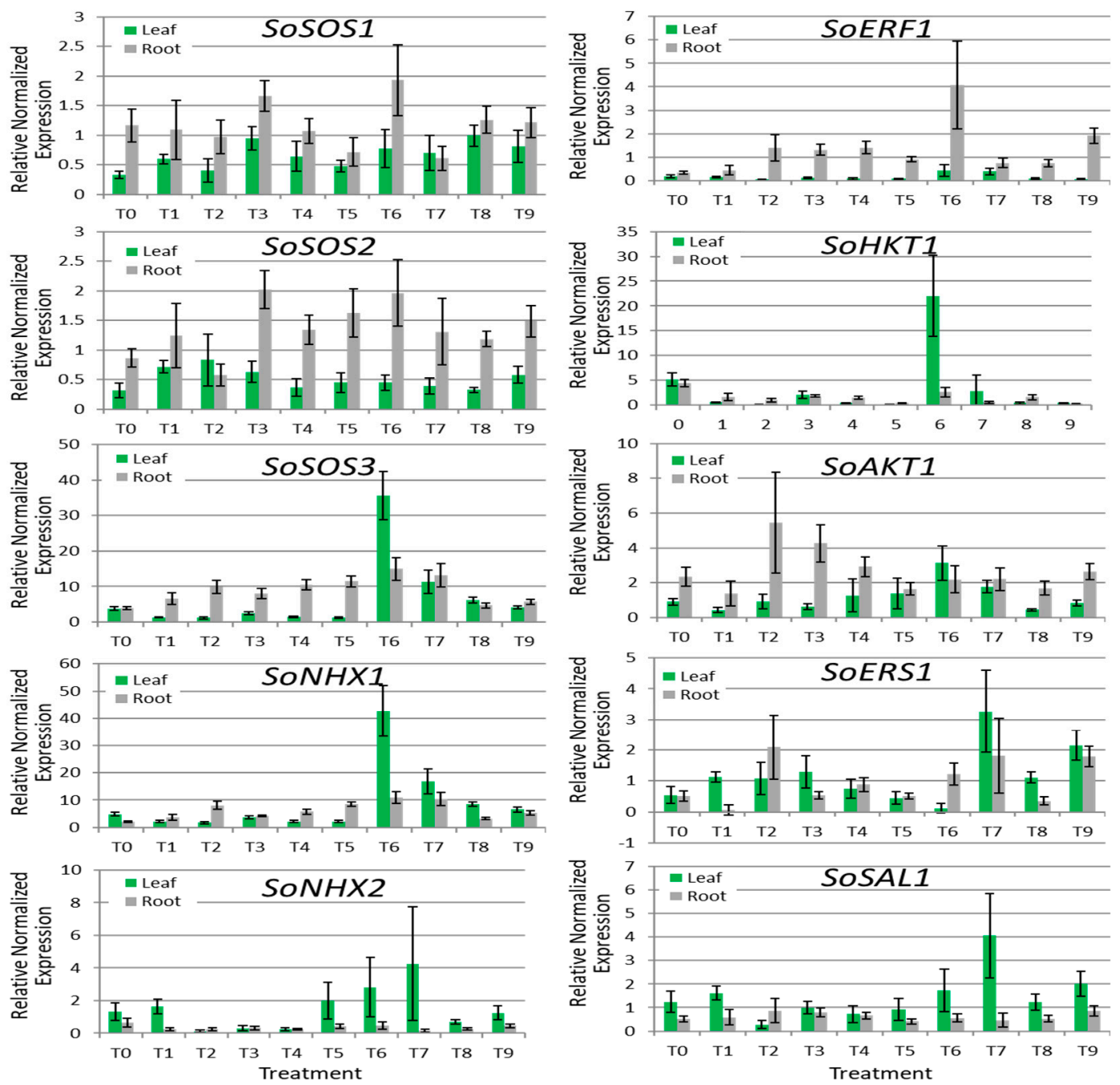

Figure 2. Gene expression in leaves and roots of Spinacia oleracea cv Raccoon in response to salinity of irrigation water with electrical conductivities $\left(\mathrm{EC}_{\mathrm{iw}}\right)$ ranging from $1.4 \mathrm{dS} \mathrm{m}^{-1}\left(2 \mathrm{meq} \mathrm{L}^{-1} \mathrm{NaCl}\right)$ to $9.8 \mathrm{dS} \mathrm{m}^{-1}$ (80 meq L $\left.{ }^{-1} \mathrm{NaCl}\right)$.

Table 5. Correlation between the expression of 10 genes in leaves and roots of Spinacea oleracea with salinity expressed as electrical conductivity of the irrigation water $\left(\mathrm{EC}_{\mathrm{iw}}\right)$.

\begin{tabular}{cccc}
\hline Gene & Tissue Expression & Correlation with $\mathbf{E C}_{\mathbf{i w}}$ & $p$ Value \\
\hline SoSOS1 & Leaf & 0.62 & 0.06 \\
& Root & -0.15 & 0.67 \\
SoSOS2 & Leaf & -0.31 & 0.39 \\
& Root & 0.22 & 0.53 \\
SoSOS3 & Leaf & 0.20 & 0.57 \\
& Root & 0.13 & 0.72 \\
SoNHX1 & Leaf & 0.26 & 0.48 \\
& Root & 0.30 & 0.40 \\
SoNHX2 & Leaf & 0.35 & 0.31 \\
& Root & -0.35 & 0.33 \\
SoERF1 & Leaf & 0.43 & 0.21 \\
& Root & 0.18 & 0.62 \\
SoHKT1 & Leaf & -0.07 & 0.85 \\
& Root & -0.62 & 0.06 \\
SoAKT1 & Leaf & 0.13 & 0.72 \\
& Root & -0.31 & 0.39 \\
SoERS1 & Leaf & 0.58 & 0.08 \\
& Root & 0.36 & 0.31 \\
SoSAL1 & Leaf & 0.55 & 0.10 \\
& Root & -0.08 & 0.82 \\
\hline
\end{tabular}




\section{Discussion}

\subsection{Salt Increase in Spinach Tissues and Mineral Tissue Composition}

Spinach accumulated more $\mathrm{Na}$ in shoots than in roots, and Na tissue accumulation increased regardless of $\mathrm{K}^{+}$concentration in irrigation waters. The increase in pot medium salinity of two-fold when water salinity went from 20 to 40 and 40 to $80 \mathrm{meq} \mathrm{L}^{-1} \mathrm{NaCl}$ reflected the two-fold increase of $\mathrm{NaCl}$ in the saline treatment water and confirmed that plants had a homogeneous salinity at their root zone. Salinity increase from control to $20 \mathrm{meq} \mathrm{L}^{-1} \mathrm{NaCl}$ resulted in 2-3 times increase in $\mathrm{Na}$ and $\mathrm{Cl}$ in both roots and shoots. This increase was also similar, but always higher for shoot $\mathrm{Na}$ (approximately $10 \mathrm{~g} \mathrm{~kg}^{-1}$ of $\mathrm{Na}$ for each increase in water salinity) than for root $\mathrm{Na}$ (approximately $3 \mathrm{~g} \mathrm{~kg}^{-1}$ ).

Literature on spinach mineral nutrients affected by abiotic stresses is scarce [25]. Although these authors did not present detailed analysis of macro and macronutrients, they reported that irrigation water with salinity of $\mathrm{EC}_{\mathrm{iw}}=6.5 \mathrm{dS} \mathrm{m}^{-1}$ reduced spinach fresh and dry weight by $34 \%$ and $27 \%$, respectively, for the $\mathrm{cv}$. Crocodile. Other research reported that $\mathrm{NaCl}$-based salinity up to a soil salinity of $\mathrm{EC}_{\mathrm{e}}=11.5 \mathrm{dS} \mathrm{m}^{-1}$ increased the concentrations of $\mathrm{N}, \mathrm{P}$, and $\mathrm{Zn}$, but decreased $\mathrm{K}$ [26]. While the concentrations of $\mathrm{Na}^{+}$and $\mathrm{Cl}^{-}$increased in spinach plants, when grown with irrigation waters of increasing salinity, our results show that spinach cv. Raccoon shoot concentrations of macro or micronutrients remained mostly unaffected (except potassium) by irrigation water salinity up to $80 \mathrm{meq} \mathrm{L}^{-1}$ of $\mathrm{NaCl}$ (approximately an $\mathrm{EC}_{\mathrm{iw}}=9.5 \mathrm{dS} \mathrm{m}^{-1}$ and an estimated soil $\mathrm{EC}_{\mathrm{e}}=4.3 \mathrm{dS} \mathrm{m}^{-1}$ ). The decrease in shoot $\mathrm{K}$ at the highest salinity treatments (T7-T9) is explained by the increase in shoot Na caused by salinity. However, tissue macro and micronutrient concentration were at sufficient levels for plant growth and development and for adequate mineral composition of shoots [27]. The concentration of $\mathrm{N}$ in shoots of our plants (4.3\%) was very similar to values recently reported [15] for baby spinach with several rates of NPK. The protein content of baby spinach reported by these authors ranged from $24-26.5 \%$, but would have ranged from $17.6-19.9 \%$ (similar to ours) had they used the same correction factor (4.39) for vegetables, which considers only protein N [24]. Other macronutrients, such as $\mathrm{K}, \mathrm{Ca}$, and $\mathrm{Mg}$ were similar to the leaf concentrations of, respectively, 70,14 , and $9 \mathrm{~g} \mathrm{~kg}^{-1}$ reported for spinach grown without saline waters [2].

Our experiment also shows clearly that 3 meq $\mathrm{L}^{-1}$ of $\mathrm{K}$ in the irrigation water is sufficient for plant growth and shoot mineral nutrients as K concentration in leaves ranged from 5.9 to $6.9 \%$, which was three-fold higher than $\mathrm{K}$ concentration in leaves of spinach plants grown with 30 to $70 \%$ of the recommended $\mathrm{K}$ dose [28]. Our plants also contained $0.4 \% \mathrm{P}$, about the same concentration as reported for spinach plants cultivated in a sandy soil containing 0.31 meq $\mathrm{L}^{-1}$ of $\mathrm{K}$, reported by these authors. Our data indicates that the irrigation water salinity used in this experiment (T1 to T9) was not high enough to affect shoot mineral nutrition of spinach

\subsection{Shoot Biomass, Antioxidant Capacity, and Oxalic Acid}

Although root biomass was significantly lower across salinity for the two higher $\mathrm{K}$ doses, this may have been caused by loss of root biomass during plant harvest, and as there was no biomass reduction for shoots (considered to develop in a close relationship with roots). The average shoot biomass accumulation in this baby spinach was fairly homogeneous reflecting the stable concentrations of macronutrients and micronutrients accumulated by the leaves, regardless of the levels of salinity and potassium doses.

Spinach antioxidants include the flavonoids kaempferol $\left(6.5 \mathrm{mg} \mathrm{kg}^{-1} \mathrm{FW}\right)$ and quercetin ( $\left.4.0 \mathrm{mg} \mathrm{kg}^{-1} \mathrm{FW}\right)$, according to the USDA Nutrient Database for Standard Reference of April 2018. According to this source, spinach also has $483 \mu \mathrm{g} 100 \mathrm{~g}^{-1} \mathrm{FW}$ of vitamin K (phylloquinone), a fat-soluble vitamin that helps blood clotting and is also an inti-inflammatory. Spinach also has unique antioxidant flavonoids identified as patuletin, spinacetin, and two hydroxylated glucuronides [29]. These authors reported that only the patuletin derivatives had significant antioxidant activity in vitro. 
The average total antioxidant capacity $\left(\mathrm{ORAC}_{\text {hydro+lipo }}\right)$ of our baby spinach leaves (immature plants) ranged from 148 to $214 \mu$ moles $\mathrm{TE}^{-1}$, and was reduced by $31 \%$ in the highest salinity level applied to the plants, regardless of $\mathrm{K}$ dose (Table 3). Our results agree with those of $\mathrm{Xu}$ and Mou [25] who reported that salinity $\left(\mathrm{EC}_{\mathrm{iw}}=6.5 \mathrm{dS} \mathrm{m} \mathrm{m}^{-1}\right)$ did not change total phenolics, but differ as they reported that leaf antioxidants (measured by the DPPH method) significantly increased with salinity. Additionally, these authors reported that $6.5 \mathrm{dS} \mathrm{m}^{-1}$ reduced dry weight by $27 \%$, indicating that their spinach cv. Crocodile was stressed by the salinity applied, while our plants of the cv Raccoon showed no decrease in shoot biomass or any visible sign of stress at $\mathrm{EC}_{\mathrm{iw}}=9.8 \mathrm{dS} \mathrm{\textrm {m } ^ { - 1 }}$. Values similar to our ORAC values (ranging from 150 to $185 \mu$ moles TE $\mathrm{g}^{-1}$ ) were reported for immature spinach by Pandjaitan et al. [30] who also observed that mid-mature spinach leaves had the highest antioxidant capacity (230 to $332 \mu$ moles TE $\mathrm{g}^{-1}$ ) compared to either immature (top) or mature (bottom) leaves. However, their values for total phenolics (18 to $30 \mathrm{mg}$ gallic acid equivalents (GAE) $\mathrm{g}^{-1} \mathrm{DW}$ ) were much higher than ours ( 3 to $4 \mathrm{mg} \mathrm{GAE}^{-1} \mathrm{DW}$ ). This difference could be explained by the fact that their plants were field grown in the fall, while our plants were spring-grown in a greenhouse.

Environmental factors, culture conditions, harvest time, and cultivars all have been reported to influence total phenolics and antioxidant capacity of strawberries [31]. However, none of these authors have evaluated the total phenolics and antioxidant capacity of spinach under salinity. Non-enzymatic antioxidants (such as flavonoids) accumulate in plant vacuoles, just as salts do, and have been linked to mechanisms of salinity tolerance in plants. The enhancement of flavonoid biosynthesis was paralleled with increased glutathione-S-transferase, involved in the transport of flavonoids to the vacuole [32] and the increase in carbon allocated to myricetin and quercetin glycosides (both antioxidant flavonols) increased significantly in salt-sensitive Myrtus communis L. compared to salt-tolerant Pistacia lentiscus L. [33]. According to the results reported by the latter authors, our results indicate that shoot antioxidants may have been used to counteract salinity effects in 'Raccoon' spinach and to maintain shoot growth.

Calcium oxalate $(\mathrm{CaOx})$ crystals occur in many plant species and in most organs and tissues, generally accumulating within cells, although it can happen extracellularly [34]. These authors reported that these plant crystals may accumulate to maintain ionic cell balance. Oxalate may be present as the soluble sodium or potassium salts or as the insoluble calcium oxalate. Although CaOx crystals have been studied in several plants, there is no evidence of its function in the plant other than ionic balance and protection against herbivory. Oxalate concentration varies from species to species, but a screening of the spinach germplasm determined that oxalate ranged from 5.3 to $11.6 \%$ in a dry weight basis [35], while other authors [2] reported spinach leaves to have $11.4 \%$ of soluble ( $\mathrm{Na}$ and $\mathrm{K}$ oxalate) and $2.2 \%$ of insoluble oxalate (CaOx). Oxalate values in this study ranged from 7.6 to $9.7 \%$ (Table 3 ). Our plant samples were extracted with hot water (not acid) to extract only the soluble Na or K oxalate. Judging from previous experiments where Na accumulation caused no visual symptoms of toxicity, we hypothesize that the extra $\mathrm{Na}^{+}$accumulating in the vacuole could have been used to make $\mathrm{Na}$ oxalate, also stored in cell vacuoles and the dominant form of oxalate in spinach [36]. These authors reported that oxalate accumulation was the highest in leaves $>$ petioles $>$ roots and ranged in leaves from 7.2 to $9.7 \%$ of DW. They also reported that soluble oxalate was lower when $\mathrm{N}$ and $\mathrm{Ca}^{2+}$ were available to plants, respectively, at 8 and $5 \mathrm{mmol} \mathrm{L}^{-1}$ and that oxalate in those plants was reduced to $9.1 \%$. Our plants were provided similar concentrations of $\mathrm{N}$ and $\mathrm{Ca}^{2+}\left(7.5 \mathrm{~N}\right.$ and $3.5 \mathrm{mmol} \mathrm{L}^{-1}$ $\mathrm{Ca}^{2+}$ ), but still had a total average oxalate concentration of $9.1 \%$ (Table 3). Thus, our data indicates that saline water at the range used in this experiment, and with the concentrations of $\mathrm{N}$ and $\mathrm{Ca}^{2+}$ used, did not increase shoot levels of oxalate in spinach and can be used to produce spinach for human consumption. However, our data also indicate that neither $\mathrm{Na}$ or $\mathrm{K}$ oxalate was involved in the salt tolerance mechanism of spinach at the salinity levels applied. 


\subsection{Leaf Photosynthetic Performance}

Spinach plants treated with saline irrigation water maintained their SPAD chlorophyll levels, but had reduced photosynthetic rate (Pn), stomatal conductance (gs), and transpiration rate (Tr). Salinity causes stomatal closure, which in turns decreases the transpiration rate, but also decreases the internal leaf $\mathrm{CO}_{2}$ levels. This decrease in internal $\mathrm{CO}_{2}$ usually accounts for the decreased $\mathrm{Pn}$ seen in our spinach plants under salinity. However, the decrease in Pn was at a lower magnitude than the decrease in $\mathrm{Tr}$, resulting in an increased water use efficiency (WUE) by spinach plants (Table 4). This increased WUE may explain the fact that this same $\mathrm{cv}$ Raccoon did better under drought conditions when irrigated with saline waters during the spring [3].

Our plants had a similar photosynthetic rate within each salinity level, indicating that $\mathrm{K}$ levels of 3, 5, and 7 meq $\mathrm{L}^{-1}$ were all sufficient for photosynthetic functions. In a previous study, $\mathrm{Xu}$ and Mou [25] found that when spinach cv. Crocodile was grown with irrigation water of $\mathrm{EC}_{\mathrm{iw}}=6.5 \mathrm{dS} \mathrm{m}^{-1}$, its shoot dry weight was significantly reduced by $27 \%$, but chlorophyll $a$ content increased significantly and chlorophyll $b$ content increased slightly, thus increasing significantly the total concentration of chlorophyll. Spinach photosynthetic capacity $\left(\mu \mathrm{mol} \mathrm{O} \mathrm{O}_{2} \mathrm{~m}^{-2} \mathrm{~s}^{-1}\right)$ increased in plants grown with both 50 (low salinity) and $250 \mathrm{mM} \mathrm{NaCl}$ (high salinity equivalent to $\mathrm{EC}_{\mathrm{iw}}=25 \mathrm{dS} \mathrm{m}^{-1}$ ) when $\mathrm{K}$ was provided as $0.01,0.1,1.0$ and $10 \mathrm{mM}$ of $\mathrm{KCl}$ [10]. However, the photosynthetic capacity was the same, regardless of salinity, when plants were provided $10 \mathrm{mM} \mathrm{KCl}$. This indicates that when $\mathrm{K}$ was deficient (doses below $10 \mathrm{mM} \mathrm{KCl}$ ) there was a $\mathrm{K}$ effect in both salinity levels, but when $\mathrm{K}$ was sufficient, the effect disappeared.

\subsection{Gene Expression Analyses}

With the objective to determine the importance of different component traits in the salt tolerance mechanism in spinach, expression analyses of 10 spinach genes known to play important role in salt tolerance in different plant species were carried out on different salt treatments. Of these genes, SOS1, SOS2 and SOS3 are known to play important role in $\mathrm{Na}^{+}$efflux from root to soil, NHX1 and NHX2 are critical for sequestering $\mathrm{Na}^{+}$in the vacuole, $H K T 1$ and $A K T 1$ are involved in retrieving $\mathrm{Na}^{+}$from xylem into root and ERS1 and SAL1 are involved in signal transduction [14,37]. The comparison of expression patterns of the genes studied showed no linear association with the salinity of the irrigation waters. The lack of direct relationship between gene expression and salinity may be due to insufficient salinity stress imposed by the salt treatments used in this study. This hypothesis is in line with the visual aspect, shoot biomass, and mineral tissue accumulation of the plants, which together indicate that $\mathrm{NaCl}$ tissue concentration were not high enough to trigger significantly different genetic expression. Additionally, the regulation of the salt tolerance mechanism may be little different in spinach as compared to Arabidopsis which may require analyses of additional genes, not included in this study. In some species such as strawberries and avocadoes, $\mathrm{Cl}^{-}$toxicity is more critical than $\mathrm{Na}^{+}$toxicity [38-40]. Analysis of some genes involved in $\mathrm{Cl}^{-}$transport is warranted to understand the role of different players in salt tolerance in spinach.

\section{Conclusions}

Physiological and genetic data corroborate that, although spinach plants absorbed and accumulated increasing amounts of $\mathrm{Na}$ and $\mathrm{Cl}$, these ions did not reach a phytotoxic level, even at 80 meq L $\mathrm{L}^{-1}$, conferred by the irrigation water with an $\mathrm{EC}_{\mathrm{iw}}$ of approximately $10 \mathrm{dS} \mathrm{m}^{-1}$. Regarding salt tolerance mechanism in spinach, our data indicates that providing $\mathrm{K}$ in excess of crop requirement will not decrease shoot accumulation of $\mathrm{Na}$ and that increased tissue $\mathrm{Na}$ was neither a hindrance nor a benefit for spinach shoot growth. Also, neither sodium or potassium oxalate seem to be involved in maintaining ionic balance in shoot tissue as accumulation of shoot $\mathrm{Na}$ did not increase soluble oxalate concentration. Spinach maintained $70 \%$ of its total antioxidant capacity at the highest salinity level $\left(\mathrm{EC}_{\mathrm{iw}}=9.8 \mathrm{dS} \mathrm{m}^{-1}\right)$ provided in the irrigation water, and the decrease in total shoot antioxidant 
capacity may have accounted for sustained plant growth and good appearance of plants throughout salinity treatments. However, more work is needed to elucidate the relationship between increased $\mathrm{Zn}$ and $\mathrm{Mn}$ in roots, decreased antioxidant capacity in shoots, and sustained shoot growth in spinach plants. Although spinach shoots are a rich source of minerals, vitamins, and antioxidants, their high concentration of oxalates (7-9\%) confirm previous statements that spinach is a not a good source of bioavailable calcium. Although our plants accumulated significantly more tissue $\mathrm{Na}$ and $\mathrm{Cl}$ at each increasing level of salinity, salinity did not cause any visual toxic effects in spinach shoots that could affect its commercial value. Thus, this study indicates that spinach can be successfully cultivated as a winter crop using waters with moderate salinity without altering its growth, overall shoot mineral composition (nutritional value), shoot oxalate concentrations, or most of its antioxidant capacity.

Supplementary Materials: The following are available online at http:/ /www.mdpi.com/2077-0472/8/10/163/s1, Table S1: Micronutrient accumulation in spinach (cv. Raccoon) irrigated with waters ranging from $20-80 \mathrm{meq} \mathrm{L}^{-1}$ of $\mathrm{NaCl}$ and three potassium $\left(\mathrm{K}^{+}\right)$concentrations. Data are means (one plant per pot) with $n=2-5$ for roots, and $4-5$ for shoots. $\mathrm{K}^{+}$was applied as $\mathrm{KNO}_{3}$ or $\mathrm{KCl}$. Numbers within brackets were not used for statistics of average data in table. Table S2: Characterization of primers $\left(5^{\prime}-3^{\prime}\right)$ used to evaluate expression analysis of target genes.

Author Contributions: Conceptualization, J.F.S.F. and D.S.; Data curation, X.L.; Formal analysis, X.L.; Investigation, J.F.S.F. and D.S.; Methodology, X.L.; Project administration, J.F.S.F. and D.S.; Software, X.L.; Visualization, J.J.H.; Writing, original draft, J.F.S.F. and D.S.; Writing, review and editing, J.F.S.F., D.S. and J.J.H.

Funding: This research was funded by the United States Department of Agriculture (USDA-ARS) as part of the internal project: CRIS 2036-13210-006-00D; Enhancing Specialty Crop Tolerance to Saline Irrigation Waters.

Acknowledgments: The authors thank Manju Pudussery to technical help and Pangki Xiong for the analyses of minerals in leaves and soil and ions in irrigation water analysis.

Conflicts of Interest: The authors declare no conflict of interest. The U.S. Department of Agriculture (USDA) prohibits discrimination in all its programs and activities on the basis of race, color, national origin, age, disability, and where applicable, sex, marital status, family status, parental status, religion, sexual orientation, genetic information, political beliefs, reprisal, or because all or part of an individual's income is derived from any public assistance program (Not all prohibited bases apply to all programs). USDA is an equal opportunity provider and employer. Mention of commercial products and organizations in this manuscript is solely to provide specific information. It does not constitute endorsement by USDA-ARS over other products and organizations not mentioned.

\section{References}

1. Heaney, R.P.; Weaver, C.M.; Recker, R.R. Calcium absorbability from spinach. Am. J. Clin. Nutr. 1988, 47, 707-709. [CrossRef] [PubMed]

2. McConn, M.M.; Nakata, P.A. Oxalate reduces calcium availability in the pads of the prickly pear cactus through formation of calcium oxalate crystals. J. Agric. Food Chem. 2004, 52, 1371-1374. [CrossRef] [PubMed]

3. Ors, S.; Suarez, D.L. Spinach biomass yield and physiological response to interactive salinity and water stress. Agric. Water Manag. 2017, 190, 31-41. [CrossRef]

4. Scudiero, E.; Corwin, D.L.; Anderson, R.G.; Yemoto, K.; Clary, W.; Wang, Z.; Skaggs, T.H. Remote sensing is a viable tool for mapping soil salinity in agricultural lands. Calif. Agric. 2017, 71, 231-238. [CrossRef]

5. Grattan, S.R.; Grieve, C.M. Salinity-mineral nutrient relations in horticultural crops. Sci. Hort. 1999, 78, 127-157. [CrossRef]

6. Kronzucker, H.J.; Coskun, D.; Schulze, L.M.; Wong, J.R.; Britto, D.T. Sodium as nutrient and toxicant. Plant Soil 2013, 369, 1-23. [CrossRef]

7. Marschner, H.; Possingham, J.V. Effect of $\mathrm{K}^{+}$and $\mathrm{Na}^{+}$on growth of leaf discs of sugar beet and spinach. Z. Pflanzenphysiol. 1975, 75, 6-16. [CrossRef]

8. Subbarao, G.V.; Ito, O.; Berry, W.L.; Wheeler, R.M. Sodium-A functional plant nutrient. Crit. Rev. Plant Sci. 2003, 22, 391-416. [CrossRef]

9. Fisarakis, I.; Chartzoulakis, K.; Stavrakas, D. Response of Sultana vines (V. vinifera L.) on six rootstocks to $\mathrm{NaCl}$ salinity exposure and recovery. Agric. Water Manag. 2001, 51, 13-27. [CrossRef]

10. Chow, W.S.; Ball, M.C.; Anderson, J.M. Growth and photosynthetic responses of spinach to salinity: Implications of $\mathrm{K}^{+}$nutrition for salt tolerance. Func. Plant Biol. 1990, 17, 563-578. [CrossRef] 
11. Alam, M.A.; Juraimi, A.S.; Rafii, M.Y.; Hamid, A.A.; Aslani, F.; Alam, M.Z. Effects of salinity and salinity-induced augmented bioactive compounds in purslane (Portulaca oleracea L.) for possible economical use. Food Chem. 2015, 169, 439-447. [CrossRef] [PubMed]

12. Petridis, A.; Therios, I.; Samouris, G.; Tananaki, C. Salinity-induced changes in phenolic compounds in leaves and roots of four olive cultivars (Olea europaea L.) and their relationship to antioxidant activity. Environ. Exp. Bot. 2012, 79, 37-43. [CrossRef]

13. Nakabayashi, R.; Yonekura-Sakakibara, K.; Urano, K.; Suzuki, M.; Yamada, Y.; Nishizawa, T.; Matsuda, F.; Kojima, M.; Sakakibara, H.; Shinozaki, K.; et al. Enhancement of oxidative and drought tolerance in Arabidopsis by overaccumulation of antioxidant flavonoids. Plant J. 2014, 77, 367-379. [CrossRef] [PubMed]

14. Sandhu, D.; Cornacchione, M.V.; Ferreira, J.F.; Suarez, D.L. Variable salinity responses of 12 alfalfa genotypes and comparative expression analyses of salt-response genes. Sci. Rep. 2017, 7, 42958. [CrossRef] [PubMed]

15. Nemadodzi, L.E.; Araya, H.; Nkomo, M.; Ngezimana, W.; Mudau, N.F. Nitrogen, phosphorus, and potassium effects on the physiology and biomass yield of baby spinach (Spinacia oleracea L.). J. Plant Nutr. 2017, 40, 2033-2044. [CrossRef]

16. Ors, S.; Suarez, D.L. Salt tolerance of spinach as related to seasonal climate. Hort. Sci. (Prague) 2016, 43, 33-41. [CrossRef]

17. Koike, S.T.; Cahn, M.; Cantwell, M.; Fennimore, S.; Lestrange, M.; Natwick, E.; Smith, R.F.; Takele, E. Spinach Production in California; UC Agriculture and Natural Resources: Davis, CA, USA, 2011; pp. 1-6.

18. Simunek, J.; Suarez, D.L. Sodic soil reclamation using multicomponent transport modeling. J. Irrig. Drain. Eng. 1997, 123, 367-376. [CrossRef]

19. Prior, R.L.; Hoang, H.; Gu, L.; Wu, X.; Bacchiocca, M.; Howard, L.; Hampsch-Woodill, M.; Huang, D.; $\mathrm{Ou}, \mathrm{B} . ; \mathrm{Jacob}, \mathrm{R}$. Assays for hydrophilic and lipophilic antioxidant capacity [oxygen radical absorbance capacity (ORAC)] of plasma and other biological and food samples. J. Agric. Food Chem. 2003, 51, 3273-3279. [CrossRef] [PubMed]

20. Slinkard, K.; Singleton, V.L. Total phenol analysis: Automation and comparison with manual methods. Am. J. Enol. Vitic. 1977, 28, 49-55.

21. Singleton, V.L.; Rossi, J.A. Colorimetry of total Phenolics with phosphomolybdic-phosphotungstic acid reagents. Am. J. Enol. Vitic. 1965, 16, 144-158.

22. Xu, C.; Jiao, C.; Sun, H.; Cai, X.; Wang, X.; Ge, C.; Zheng, Y.; Liu, W.; Sun, X.; Xu, Y.; et al. Draft genome of spinach and transcriptome diversity of 120 Spinacia accessions. Nat. Commun. 2017, 8, 15275. [CrossRef] [PubMed]

23. Vandesompele, J.; De Preter, K.; Pattyn, F.; Poppe, B.; Van Roy, N.; De Paepe, A.; Speleman, F. Accurate normalization of real-time quantitative RT-PCR data by geometric averaging of multiple internal control genes. Genome Biol. 2002, 3, RESEARCH0034. [CrossRef] [PubMed]

24. Fujihara, S.; Kasuga, A.; Aoyagi, Y. Nitrogen-to-protein conversion factors for common vegetables in Japan. J. Food Sci. 2001, 66, 412-415. [CrossRef]

25. Xu, C.; Mou, B. Responses of spinach to salinity and nutrient deficiency in growth, physiology, and nutritional value. J. Am. Soc. Hort. Sci. 2016, 141, 12-21.

26. Sheikhi, J.; Ronaghi, A. Growth and macro and micronutrients concentration in spinach (Spinacia oleracea L.) as influenced by salinity and nitrogen rates. Int. Res. J. Appl. Basic Sci. 2012, 3, 770-777.

27. Gülser, F. Effects of ammonium sulphate and urea on $\mathrm{NO}_{3}{ }^{-}$and $\mathrm{NO}_{2}-$ accumulation, nutrient contents and yield criteria in spinach. Sci. Hortic. 2005, 106, 330-340. [CrossRef]

28. Aisha, H.A.; Hafez, M.M.; Asmaa, R.M.; Shafeek, M.R. Effect of bio and chemical fertilizers on growth, yield and chemical properties of spinach plant (Spinacia oleracea L.). Middle East J. 2013, 2, 16-20.

29. Howard, L.R.; Pandjaitan, N.; Morelock, T.; Gil, M.I. Antioxidant capacity and phenolic content of spinach as affected by genetics and growing season. J. Agric. Food Chem. 2002, 50, 5891-5896. [CrossRef] [PubMed]

30. Pandjaitan, N.; Howard, L.R.; Morelock, T.; Gil, M.I. Antioxidant capacity and phenolic content of spinach as affected by genetics and maturation. J. Agric. Food Chem. 2005, 53, 8618-8623. [CrossRef] [PubMed]

31. Pincemail, J.; Kevers, C.; Tabart, J.; Defraigne, J.O.; Dommes, J. Cultivars, culture conditions, and harvest time influence phenolic and ascorbic acid contents and antioxidant capacity of strawberry (Fragaria $\times$ ananassa). J. Food Sci. 2012, 77, C205-C210. [CrossRef] [PubMed]

32. Zhao, J.; Dixon, R.A. The 'ins' and 'outs' of flavonoid transport. Trend. Plant Sci. 2010, 15, 72-80. [CrossRef] [PubMed] 
33. Tattini, M.; Remorini, D.; Pinelli, P.; Agati, G.; Saracini, E.; Traversi, M.L.; Massai, R. Morpho-anatomical, physiological and biochemical adjustments in response to root zone salinity stress and high solar radiation in two Mediterranean evergreen shrubs, Myrtus communis and Pistacia lentiscus. New Phytol. 2006, 170, 779-794. [CrossRef] [PubMed]

34. Franceschi, V.R.; Horner, H.T. Calcium oxalate crystals in plants. Bot. Rev. 1980, 46, 361-427. [CrossRef]

35. Mou, B. Evaluation of oxalate concentration in the U.S. spinach germplasm collection. HortScience 2008, 43, 1690-1693.

36. Zhang, Y.; Li, Y.; Wei, J.; Sun, M.; Tian, Y.; Li, Z. Effects of nitrogen and calcium nutrition on oxalate contents, forms, and distribution in spinach. J. Plant Nutr. 2009, 32, 2123-2139. [CrossRef]

37. Munns, R.; Tester, M. Mechanisms of salinity tolerance. Annu. Rev. Plant Biol. 2008, 59, 651-681. [CrossRef] [PubMed]

38. Li, B.; Tester, M.; Gilliham, M. Chloride on the Move. Trend. Plant Sci. 2017, 22, 236-248. [CrossRef] [PubMed]

39. Suarez, D.L.; Grieve, C.M. Growth, yield, and ion relations of strawberry in response to irrigation with chloride-dominated waters. J. Plant Nutr. 2013, 36, 1963-1981. [CrossRef]

40. Tregeagle, J.M.; Tisdall, J.M.; Tester, M.; Walker, R.R. $\mathrm{Cl}^{-}$uptake, transport and accumulation in grapevine rootstocks of differing capacity for $\mathrm{Cl}^{-}$exclusion. Funct. Plant Biol. 2010, 37, 665-673. [CrossRef]

(C) 2018 by the authors. Licensee MDPI, Basel, Switzerland. This article is an open access article distributed under the terms and conditions of the Creative Commons Attribution (CC BY) license (http:/ / creativecommons.org/licenses/by/4.0/). 